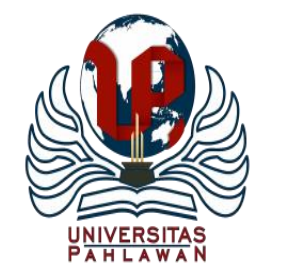

Jurnal Basicedu Volume 2 Nomor 1 April 2020 Halaman 8-14

EDUKATIF: JURNAL ILMU PENDIDIKAN

Research \& Learning inEducation

https://edukatif.org/index.php/edukatif/index

\title{
Pengembangan Media E-Learning Berbasis Schoology pada Pembelajaran Kurikulum Pendidikan Teknologi dan Kejuruan
}

\author{
Rini Sefriani ${ }^{1}$, Rina Sepriana ${ }^{2}$, \\ , Universitas Putra Indonesia Yptk Padang, Sumatera Barat, Indonesia 1,2 \\ e-mail :rinisefriani@upiyptk.ac.id ${ }^{1}$, rinasepriana3@ gmail.com $^{2}$
}

\begin{abstract}
Abstrak
Penelitian ini dilakukan berdasarkan permasalahan yaitu belum maksimalnya pemanfaatan fasilitas hotspot untuk kebutuhan pembelajaran oleh mahasiswa di Kampus, serta masih rendahnya kemampuan literasi digital mahasiswa. Penelitian bertujuan untuk mengtahui tingkat validitas, praktikalitas dan efektifitas media elearning berbasis schoology pada pembelajaran Kurikulum Pendidikan Teknologi dan Kejuruan. Jenis penelitian ini adalah Research and Development (R\&D) dengan menggunakan model pengembangan ADDIE. Instrument dalam penelitian ini adalah angket dan soal tes. Sampel dalam penelitian ini sebanyak 30 orang mahasiswa jurusan Pendidikan Teknik Informatika Fakultas Keguruan dan Ilmu Pendidikan Universitas Putra Indonesia Yptk Padang. Hasil penelitian menunjukkan bahwa ingkat validitas media e-learning berbasis schoology diperoleh sebesar 84,25\% dengan interpretasi valid digunakan, untuk tingkat tingkat praktikalitas diperoleh sebesar 85,64\% yang berarti sangat praktisdigunakan oleh pendidik dan mahasiswa dan untuk tingkat uji efektifitas dengan menggunakan uji N-gain diperoleh nilai skor N-gain sebesar0,667 yang berarti efektif menggunakanmedia E-Learning Berbasis Schoology pada Pembelajaran Kurikulum Pendidikan Teknologi dan Kejuruan. Dapat disimpulkan bahwa penggunaan schoology dalam pembelajaran e-learning dapat mengoptimalkan kemampuan literasi digital mahasiswa.
\end{abstract}

Kata Kunci: E-Learning, Schoology, Literasi Digital.

\begin{abstract}
This research was conducted based on the problem that is not yet the maximum utilization of hotspot facilities for learning needs by students on campus, as well as the low ability of digital literacy of students. The research aims to find out the level of validity, practicality and effectiveness of school-based e-learning media on learning of the Technology and Vocational Education Curriculum. This type of research is Research and Development $(R \& D)$ using the ADDIE development model. The instruments in this study were questionnaires and test questions. The samples in this study were 30 students majoring in Informatics Engineering Education, Faculty of Teacher Training and Education, Putra Indonesia University Yptk Padang. The results showed that the validity level of school-based e-learning media was $84.25 \%$ with valid interpretation used, for the practicality level was $85.64 \%$ which meant that it was very practical to be used by educators and students and for the level of effectiveness test using the test $\mathrm{N}$-gain value obtained $\mathrm{N}$-gain score of 0.667 , which means effectively using the School-Based E-Learning media in Learning Technology and Vocational Education Curriculum. It can be concluded that the use of schoology in e-learning learning can optimize student digital literacy abilities.
\end{abstract}

Keywords:E-Learning, Schoology, Digital Literacy.

@Edukasi: Jurnal Ilmu Pendidikan 2020

$\triangle$ Corresponding author :

Address : Universitas Putra Indonesia Yptk Padang $\quad$ ISSN 2656-8063 (Media Cetak)

Email : rinisefriani@upiyptk.ac.id ISSN 2656-8071 (Media Online)

Phone : 081374664377 
9 Pengembangan Media E-Learning Berbasis Schoology pada pembelajaran Kurikulum Pendidikan Teknologi dan Kejuruan - Rini Sefriani, Rina Sefriana

\section{PENDAHULUAN}

Kemajuan ilmu pengetahuan dan teknologi berkembang begitu cepat, seperti berlari dengan waktu, manusia berlomba-lomba untuk menemukan cara - cara yang praktis untuk menunjang pekerjaannya.Sehingga memberikan kemudahan dalam setiap bidang kehidupan manusia.Salah satunya adalah penggunaan $e$ learningdalam pendidikan tinggi yang bermanfaat bagi dosen dan mahasiswa pada saat proses pembelajaran. E-learningmerupakan suatu sistem atau konsep pendidikan yang memanfaatkan teknologi informasi dan komunikasi dalam proses belajar mengajar.E-learning sebagai media merupakan media berbasis web yang menyediakan fasilitas pembelajaran digital online.

Proses pembelajaran secara online menggunakan E-Learning dapat melatih peserta didik untuk belajar secara mandiri, sehingga pembelajaran dapat bergeser kepada pembelajaran yang berpusat pada siswa atau student center learning, yang santa dianjurkan oleh pemerintah sekarang ini. Pemanfaatan fasilitas internet yang disediakan oleh pihak perguruan tinggi dalam hal ini Universitas Putra Indonesia Yptk Padang untuk mahasiswanya sudah sangat memadai, akan tetapi belum maksimal dimanfaatkan oleh mahasiswa dalam pembelajaran. Mahasiswa mengakses internet lebih cendrung hanya untuk melihat media social seperti facebook, instagram, whatsapp serta video yang di tayangkan melalui youtube. Hal ini tentu sangat tidak menguntungkan bagi mahasiswa itu sendiri, maka perlu diadakan pembelajaran yang menggunakan akses internet yang membantu mahasiswa dalam peningkatan pembelajaran dengan harapan meningkatkan kemampuan literasi digital mahasiwa. Penggunaan literasi digital yang sudah sangat banyak tersedia di dunia maya akan berdampak baik kepada mahasiswa itu sendiri. Untuk membantu mahasiswa dalam peningkatan kemampuan lietrasi digital salah satu nya dengan memberikan pembelajaran secara online dengan memanfaatkan media Learning Management System (LMS) yang bersifat gratis. Salah satu LMS yang sudah banyak dimanfaatkan oleh pengajar baik itu dosen atau guru adalah aplikasi schoology.

Schoology adalah salah satu media Learning Management System (LMS), dimana LMS sendiri adalah aplikasi perangkat lunak atau teknologi berbasis web yang digunakan untuk merencanakan, melaksanakan dan menilai proses pembelajaran tertentu. Media pembelajaran shoology ini tidak hanya media pembelajaran yang biasa melainkan dengan menggunakan pendekatan realistik sehingga sangat diharapkan dapat meningkatkan kemampuan literasi mahasiswaHidayat, Y. N., dkk (2019).Penelitian yang dilakukan oleh Suana, W., dkk (2017) mengemukakan bahwa pembelajaran dengan menggunakan aplikasi schoology dapat meningkatkan kemampuan dan motivasi belajar mahasiswa. Hal yang sama juga dikemukakan oleh Putri, N. W. M. A., dkk (2014) bahwa hasil belajar siswa mengalami peningkatan rata-rata setelah mengalami pembelajaran dengan menggunakan media pembelajaran aplikasi schoology. Berbeda dengan yang dikemukakan oleh Aminoto, T. (2014) bahwa dengan pemanfaatan schoology di rumah ternyata membuat aktivitas danhasil belajar siswa menurun dikarenakan faktor teknis dan non teknis.

Berbeda dengan Irawan, V. T., Sutadji, E., \& Widiyanti. (2017) mengatakan bahwa dengan Blended Learning terbukti meningkatkan hasil belajar lebih baik daripada Probem Based Learning. Pembelajaran dengan Schoology mampu meningkatkan aktivitas siswa di luar jam sekolah untuk mengeksplorasi materi secara individual dan mandiri. Siswa dapat mengikuti pembelajaran online tentang Schoology menggunakan laptop, komputer pribadi, atau smartphone. Pembelajaran dengan Schoology juga mampu meningkatkan 
10 Pengembangan Media E-Learning Berbasis Schoology pada pembelajaran Kurikulum Pendidikan Teknologi dan Kejuruan - Rini Sefriani, Rina Sefriana

interaksi yang terkait dengan pembelajaran antara teman sebaya di luar sekolah; ini terbukti dari meningkatnya pembelajaran kelompok dan diskusi di antara teman sebaya di luar sekolah untuk belajar bersama di Schoology. Aspek terbaik dari menggabungkan studi kelas dan pembelajaran di Schoology adalah untuk membuat penguasaan konsep siswa meningkat karena materi yang diperoleh dari berbagai sumber. Sehingga kemampuan siswa di kelas meningkat.Pembelajaran dengan menggunakan media lain selain buku teks sebenarnya sangat membatu siswa untuk belajar mandiri dan mampu meningkatkan hasil belajar serta aktivitas siswa, sesuai dengan penelitian yang telah dilakukan oleh Wijaya, I., \& Sefriani, R. (2016). Pada tahun berikutnya Wijaya, I., \& Sefriani, R. (2017) juga melakukan penelitian mengenai penggunaan modul dalam pembelajaran yang juga dapat meningkatkan hasil belajar siswa, serta modul yang dihasilkan termasuk kategori sangat valid, sangat paktis dan sangat efektif digunakan dalam pembelajaran. Kehadiran media lain dalam proses pembelajaran menjadikan pembelajaran berbeda dengan sebelumnya seperti yang penelitian oleh Sefriani, R., \& Veri, J. (2018) dimana menghadirkan pembelajaran dengan mobile learning, dimana siswa bisa mengakses pembelajaran dengan menggunakan smartphone. Sefriani, R., \& Wijaya, I. (2018) dalam penelitiannya juga berbicara tentang media pembelajaran dengan modul multimedia interaktif, yang menuntut siswa untuk mampu belajar seara mandiri. Jafnihirda, L., Diani, D., \& Sefriani, R. (2019) menghadirkan buku berbentuk digital dengan dilengkapi tugas untuk siswa, sehingga memacu siswa untuk mengakses modul yang diberikan. Sefriani, R., Wijaya, I., \& Radyuli, P. (2018) berupaya juga menghadirkan media pembelajaran dalam bentuk berbasos android dengan harapan siswa dapat memanfaatkansmartphone android yang mereka miliki memiliki fungsi yang lebih baik dalam pembelajaran, dimana siwa dpat mengakses pembelajaran yang sudah di hasilkan dengan lebih leluasa.

Radyuli, P., Sefriani, R. S., \& Qomariah, N. (2019) dalam penelitiannya memanfaatkan google form dalam pembelajaran sebagai media tambahan atau alat bantu untuk proses belajar mengajar, dalam peenlitiannya Radyuli pengemukakan bahwa dengan adanya media google form mampu meningkatkan hasil belajar siswa. Dengan demikian banyak media lain yang bisa dimanfaatkan dalam pembelajaran terutama media online, seperti google form ini. Berdasarkan paparan sebelumnya maka sebagai solusi cedas untuk membantu mahasiswa dalam meningkatkan kemampuan literasi digital dan pemanfaatan fasilital internet oleh siswa maka dikembangkan media pembelajaran e-learning berbasis schoologi pada pembelajaran Kurikulum Pendidikan Teknologi dan Kejuruan. Adam dan Hamm (2001) mengatakanbahwa literasi merupakan kemampuan untuk membaca, menulis, berbicara,mendengar, berpikir dan melihat, Definisi literasi digitalmenurut James Potter ialah sebagai berikut

"A set of perspectives that we actively expose
ourselves to the media to interpret the meaning
of the messages we encounter. We build our
perspectives from knowledge structures. To
build our knowledge structures, we need tools
and raw material. These tools are our skills.
The raw material is information from the media
and the real world. Active use means that we
are aware of the messages and are consciously
interacting with them (Potter, 2005: 22)."

Literasi digital menurut Potter adalahketertarikan, sikap, dan kemampuanindividu dalam menggunakan teknologidigital dan alat komunikasi untukmengakses, mengelola, mengintegrasikan,menganalisis dan mengevaluasi informasi,membangun pengetahuan baru, membuat danberkomunikasi dengan orang lain 
11 Pengembangan Media E-Learning Berbasis Schoology pada pembelajaran Kurikulum Pendidikan Teknologi dan Kejuruan - Rini Sefriani, Rina Sefriana

agar dapatberpartisipasi secara efektif dalam masyarakat.Dengan demikian kemampuan literasi digital mahasiswa dalam pembelajaran kurikulum Pendidikan teknologi dan kejuruan berarti ketersediaan media pembelajaran yang terkait. Dosen menggunakan schoology sebagai media untuk e-Learning. Ini menciptakan suasana belajar virtual di kelas Kurikulum Pendidikan dan teknologi Kejuruan pendidikan tinggi.

Mata kuliah Kurikulum Pendidikan dan teknologi Kejuruan merupakan mata kuliah yang diberikan kepada mahasiswa Jurusan Pendidikan Teknik Informatika yang berada di semester 6 . Mata kuliah ini berisikan tentang konsep kurikulum secara umum, dan kurikulum di Sekolah Kejuruan,

\section{METODE PENELITIAN}

Penelitian ini menggunakan model pengembangan ADDIE, yang meliputi 5 tahap yaituanalysis, design, development, implementation, dan evaluation ( Aththibby, 2015)

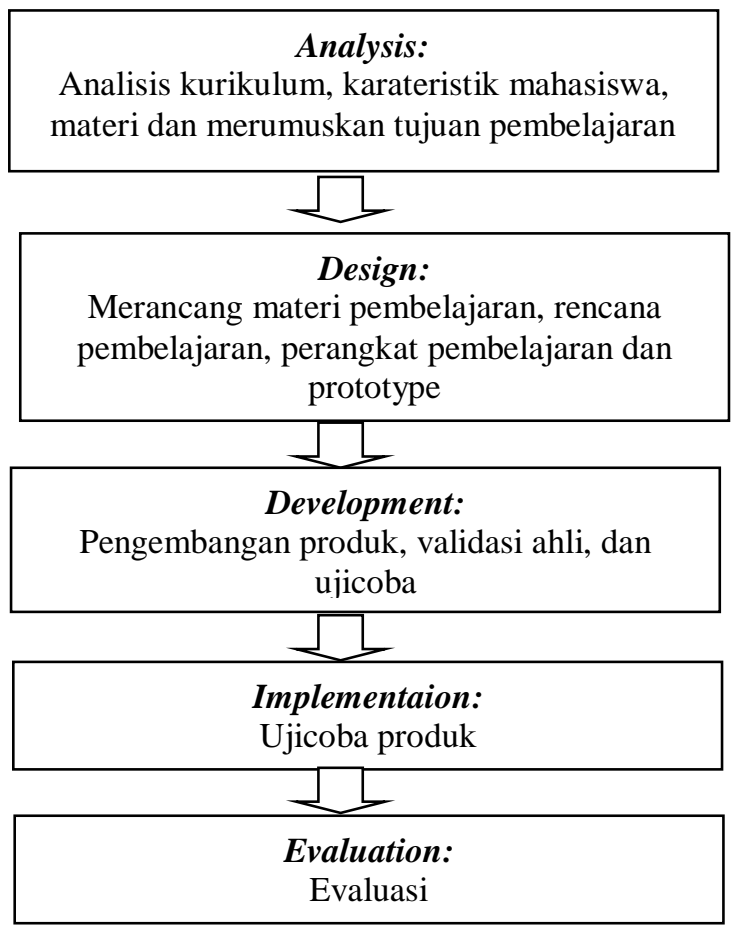

Gambar 1. Diagram Alur pengembangan e-learning

Subjek penelitian dalam penelitian ini adalah mahasiswa tingkat 3 atau semester 6 jurusan Pendidikan Teknik Informatika FKIP
Universitas Putra Indonesia Yptk Padang. Jumlah mahasiswa sebanyak 30 orang mahasiswa terdiri atas laki-laki 11 orang dan perempuan 19 orang. Objek penelitian adalah kelayakan media elearning berbasis schoology pada materi model pengembangan kurikulum dan komponen kurikulum. Instrument penelitian pada pengembangan ini adalah lembar validasi, RPS dan tes hasil belajar. Validasi diukur menggunakan lembar validasi yang diberi penilaian oleh tiga orang, meliputi praktisi dan akademisi.

Table 1. Klasifikasi Validitas

\begin{tabular}{lll}
\hline No & Nilai Rerata & Keterangan \\
\hline 1 & $90 \%-100 \%$ & Sangat Valid \\
2 & $80 \%-89 \%$ & Valid \\
3 & $65 \%-79 \%$ & Cukup Valid \\
4 & $55 \%-64 \%$ & Kurang Valid \\
\hline 5 & $\leq \quad 54 \%$ & Tidak Valid \\
\hline & Sumber : Purwanto $(2010)$
\end{tabular}

Table 2. Klasifikasi Praktikalitas

\begin{tabular}{|l|l|l|}
\hline No & Nilai & Aspek Yang Dinilai \\
\hline 1 & $86 \%-100 \%$ & Sangat Praktis \\
\hline 2 & $76 \%-85 \%$ & Praktis \\
\hline 3 & $60 \%-75 \%$ & Cukup Praktis \\
\hline 4 & $55 \%-59 \%$ & Kurang Praktis \\
\hline 5 & $\leq \quad 54 \%$ & Tidak Praktis \\
\hline
\end{tabular}

$<\mathrm{g}>=\frac{S_{\text {post }}-S_{\text {pre }}}{S_{\text {maks }}-S_{\text {pre }}}$

$$
\begin{aligned}
& \text { Keterangan: } \\
& S_{\text {post }}=\text { skor postes } \\
& S_{\text {pre }}=\text { skor pretes } \\
& S_{\text {maks }}=\text { skor maksimum }
\end{aligned}
$$

Tabel 3. Klasifikasi efektifitas dengan N-gain

\begin{tabular}{cc}
\hline Besar $g$ & Interpretasi \\
\hline$<\mathrm{g}>0,70$ & Tinggi \\
$0,30<<\mathrm{g}>\leq 0,70$ & Sedang \\
$<\mathrm{g}>\leq 0,30$ & Rendah \\
\hline
\end{tabular}

\section{HASIL DAN PEMBAHASAN PENELITIAN}

Produk dari penelitian dan pengmbangan ini adalah dalam bentuk pengembangan media elearning berbasis schoology dengan dilengkapi materi dan tugas yang disesuaikan dengan 
12 Pengembangan Media E-Learning Berbasis Schoology pada pembelajaran Kurikulum Pendidikan Teknologi dan Kejuruan - Rini Sefriani, Rina Sefriana

rancangan pembelajaran semester atau RPS.

Produk media pembelajaran ini dibuat dan dirancang disesuaikan dengan materi model-model kurikulum dan kompoen kurikulum serta ada beberapa tambahan materi lainnya, dengan tujuan dapat digunakan sebagai alat bantu dosen dalam menyampaikan materi dan juga sebagai sumber belajar mandiri yang sewaktu- waktu dapat digunakan oleh mahasiswa di luar waktu pembelajaran di kampus.

Pengembangan media e-learningini menggunakan model perancangan ADDIE. Model ADDIE memiliki 5 tahapan antara lain Analysis (Analisis), Design (Desain), Development (Pengembangan), Implementation (Implementasi) dan Evaluation (Evaluasi). Penelitian pengembangan model ADDIE yang dilakukan hanya sampai tahap Development (Pengembangan), karena tujuan penelitian ini hanya sebatas mengembangkan dan menghasilkan suatu media pembelajaran yang valid untuk diimplementasikan berdasarkan penilaian validator. Berikut disajikan Tahapan penelitian pengembangan seperti dibawah ini:

1. Analysis (Analisis), tahap analisis terhadap pengembangan produk yang dilakukan terdiri dari analisis materi dan analis media pembelajaran.

2. Design ( Desain), pada tahap Merancang materi pembelajaran, rencana pembelajaran, perangkat pembelajaran dan prototype. Dasain tugas, diskusi serta tampilan materi pembelajaran yang disajikan.

3. Development (Pengembangan), pada tahap ini Pengembangan produk, validasi ahli, dan ujicoba

4. Implementation (Uji coba Produk), yaitu pada tahap ini dilakukan uji coba produk pada mahasiswa lain selain mahasiswa subjek penelitian

5. Evaluation (evaluasi), tahap ini adalah tahap dimana uji efektifitas dilaksanakan setelah ujicoba produk dilakukan.

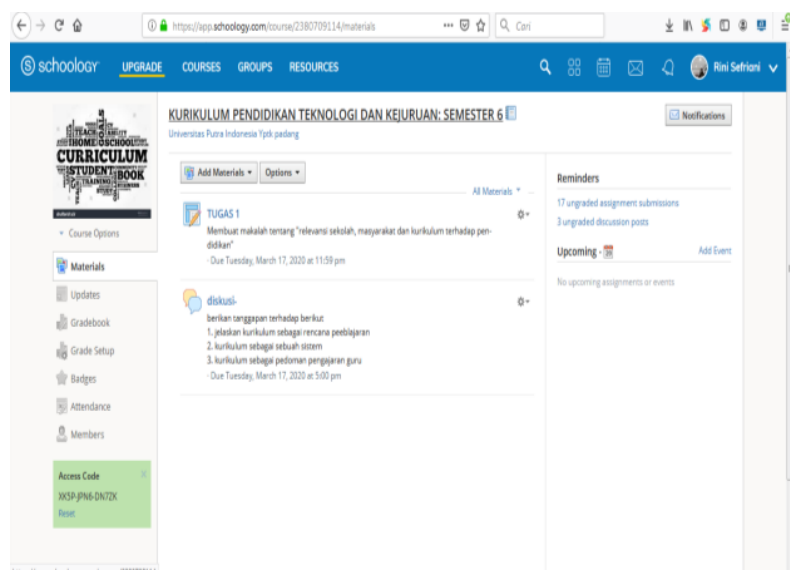

Gambar 2. Tampilan media e-learning berbasis schoology.

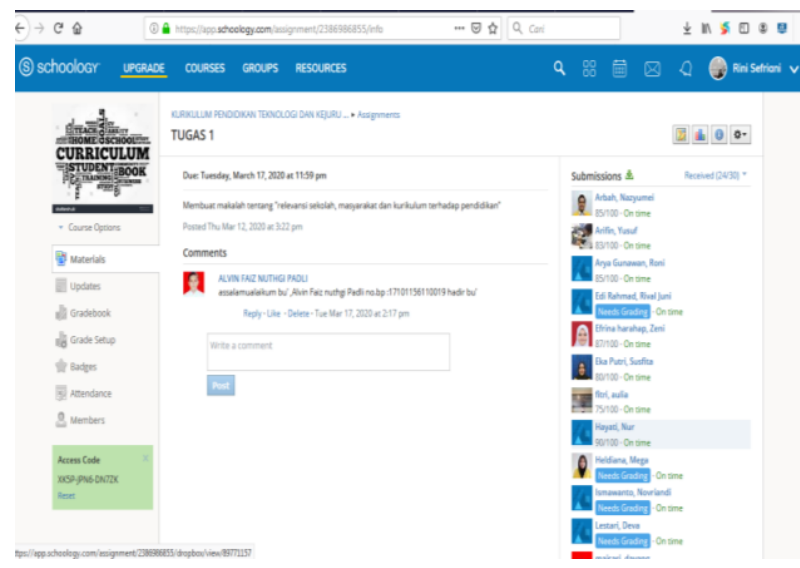

Gambar 3. Tampilan tugas 1 dan pemberian skor (nilai)

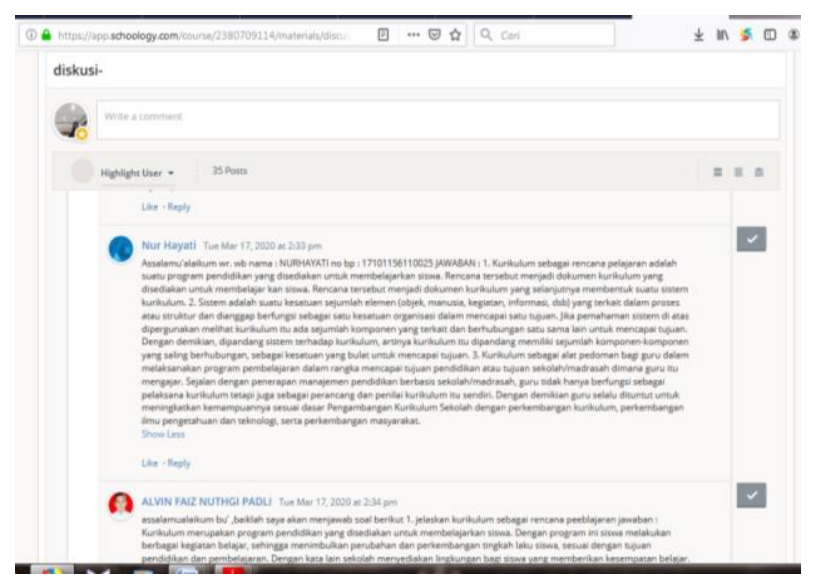

Gambar 4. Tampilan diskusi mahasiswa dilengkapi dengan pemberina skor ( nilai)

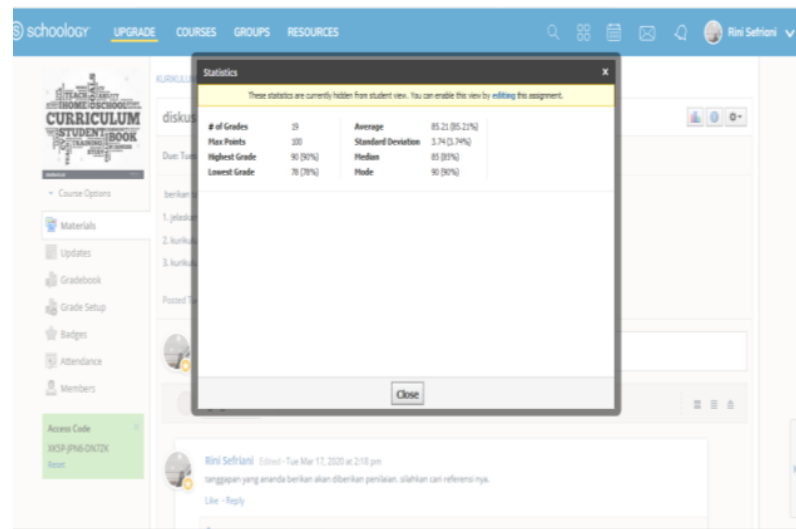

Gambar 5. Statistic perolehan skor ( nilai ) 
13 Pengembangan Media E-Learning Berbasis Schoology pada pembelajaran Kurikulum Pendidikan Teknologi dan Kejuruan - Rini Sefriani, Rina Sefriana

a. Validitas Produk media e-learning berbasis schoology

Table 4. Nilai validitas

\begin{tabular}{|l|l|l|}
\hline No & Aspek & Persentase \\
\hline 1 & Kelayakan Isi & $88 \%$ \\
\hline 2 & Kebahasaan & $83 \%$ \\
\hline 3 & Penyajian & $83 \%$ \\
\hline 4 & Kegrafikan & $83 \%$ \\
\hline \multicolumn{2}{|l|}{ Rata-rata } & $84,25 \%$ \\
\hline
\end{tabular}

Berdasarkan table 4 dapat dilihat bahwa produk media e-learning berbasis schoology sudah layak atau valid digunakan dalam proses pembelajaran. Hal ini ditunjukkan dengan tingkat rata-rata nilai validitas sebesar 84, $25 \%$ yang berarti, media e-learning berbasis schoology valid digunakan.

b. Praktikalitas Produk media e-learning berbasis schoology

Tabel 5. Nilai Praktikalitas

\begin{tabular}{|c|c|c|}
\hline No & Aspek & Persentase \\
\hline 1 & Keadaan penggunaan & $85,29 \%$ \\
\hline 2 & $\begin{array}{ll}\text { Efektifitas } & \text { waktu } \\
\text { pembelajaran } & \end{array}$ & $88,89 \%$ \\
\hline 3 & Manfaat & $82,75 \%$ \\
\hline \multicolumn{2}{|c|}{ Rata-rata } & $85,64 \%$ \\
\hline
\end{tabular}

Berdasarkan table 5 dapat dilihat bahwa produk media e-learning berbasis schoology sudah sangat praktis digunakan dalam proses pembelajaran. Hal ini ditunjukkan dengan tingkat rata-rata nilai praktikalitas sebesar 85, $64 \%$ yang berarti, media e-learning berbasis schoology sangat praktis digunakan.

c. Efektifitas Produk media e-learning berbasis schoology

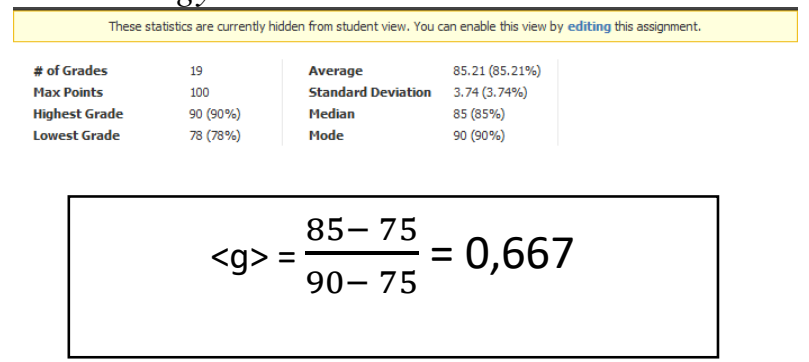

Berdasarkan data dia atas didapat nilai $\mathrm{N}$ gain sebesar 0,667, yang berarti termasuk kategori sedang. Dengan demikian, media elearning berbasis schoology efektif meningkatkan kemampuan hasil belajar mahasiswa.

Berdasarkan hasil analisis validitas, praktikalitas dan efektifitas media e-lerning berbasis schoology yang sudah dilakukan, dapat dikatakan bahwa produk media e-learningschoologymampu menjadi sarana dalam proses pembelajaranyang memberikan dampak positif sehingga hasil belajar mahasiswa meningkat. Sesuai dengan penelitian yang dilakukan oleh Putri, N. W. M. A., Jampel, I. N., \& Suartama, I. K. (2014) dimana juga mampumenigkatan hasil belajar siswa dengan adanya media e-learning schoology. Didukung juga oleh penelitian yang dilakukan oleh Suana, W., Maharta, N., Nyeneng, I. D., \& Wahyuni, S. (2017) yang menghasilkan media yang valid, praktis dan efektif serta penerapan nya juga mampu meningkatkan hasil belajar. Dengan demikian dapat dikatakan bahwa menghadirkan media online dalam proses pembelajaran memberikan kesempatan kepada mahasiswa untuk memberikan pendapat secara tulisan. Dilihat juga dari kemampuan literasi digital mahasiswa dengan indikator pada ketepatan mahasiswa dalam memberikan tanggapan terhadap materi diskusi yang diberikan. Yaitu, meminta mahasiswa untu menyertakan sumber/referensi belajaryang mereka dapatkan. Sehingga literasi digital mahasiswa menjadi semakin menigkat.

\section{UCAPAN TERIMA KASIH}

Penulis mengucapkan terima kasih kepada Rektor Universitas Putra Indonesia Yptk Padang Dekan FKIP UPI Yptk Padang, Ketua LPPM, serta dosen dan mahasiswa yang telah berkontribusi dalam penyelesaian penelitian ini.

\section{KESIMPULAN}

Penggunanaan media online sebagai sarana untuk alat bantu dalam proses pembelajaran akan memberikan variasi pada proses pembelajaran. Hal 
14 Pengembangan Media E-Learning Berbasis Schoology pada pembelajaran Kurikulum Pendidikan Teknologi dan Kejuruan - Rini Sefriani, Rina Sefriana

ini juga memberikan dampak yang positif kepada mahasiswa, yaitu dapat meningkatkan hasil belajar siswa serta mengasah kemampuan literasi digital mahasiswa. Salah satu aplikasi Learning Management Sstem ( LMS) yang tadak berbayar adalah aplikasi schoology.

\section{DAFTAR PUSTAKA}

Hidayat, Y. N., Wardono, W., \& Rusilowati, A. (2019, February). Analisis Kemampuan Literasi Matematika Ditinjau Dari Metakognisi Siswa dalam Pembelajaran Synectics Berbantuan Schoology. In PRISMA, Prosiding Seminar Nasional Matematika (Vol. 2, pp. 911-916).

Aminoto, T. (2014). Penerapan media e-learning berbasis schoology untuk meningkatkan aktivitas dan hasil belajar materi usaha dan energi di kelas xi sma n 10 kota jambi. Sainmatika: Jurnal Sains dan Matematika Universitas Jambi, 8(1).

Putri, N. W. M. A., Jampel, I. N., \& Suartama, I. K. (2014). Pengembangan E-Learning Berbasis Schoology pada Mata Pelajaran IPA Kelas VIII di SMP Negeri 1 Seririt. Jurnal EDUTECH Undiksha, 2(1).

Suana, W., Maharta, N., Nyeneng, I. D., \& Wahyuni, S. (2017). Design and implementation of schoology-based blended learning media for basic physics I course. Jurnal Pendidikan IPA Indonesia, 6(1).

Irawan, V. T., Sutadji, E., \& Widiyanti. (2017). Blended learning based on schoology: Effort of improvement learning outcome and practicum chance in vocational high school. Cogent Education, 4(1), 1282031.

Wijaya, I., \& Sefriani, R. (2016). Interactive Multimedia CD Design Chemistry Lesson In Concept Training Material and amendment For Class X Vocational High School (SMK). JOURNAL OF DYNAMICS (International Journal of Dynamics in Engineering and Sciences), 1(1).

Wijaya, I., \& Sefriani, R. (2017). Interactive Modules Based Adobe Director On Computer Assembling Subjects For Vocational Secondary School Students. VOLT: Jurnal Ilmiah Pendidikan Teknik Elektro, 2(2), 73-80.
Sefriani, R., \& Wijaya, I. (2018). Pembuatan Modul Pembelajaran Multimedia Interaktif Berbasis Adobe Director Pada Mata Pelajaran Sistem Operasi Sekolah Menengah Kejuruan. INTECOMS: Journal of Information Technology and Computer Science, 1(1), 60-71.

Sefriani, R., \& Veri, J. (2018). Pengembangan Mobile Learning Berbasis Client Server Pada Mata Pelajaran Simulasi Digital. Jurnal KomtekInfo, 5(3), 61-71.

Jafnihirda, L., Diani, D., \& Sefriani, R. (2019). Modul, 3D Pageflip Profesional, pengembangan modul pembelajaran desain grfais berbasis $3 \mathrm{~d}$ pagefelip professional. Jurnal pti (pendidikan dan teknologi informasi) fakultas keguruan ilmu pendidikan universita putra indonesia" yptk" padang, 6(1), 45-54.

Sefriani, R., Wijaya, I., \& Radyuli, P. (2018). Development of android based learning media on the subjects of digital photo composition for vocational high school student. VOLT: Jurnal Ilmiah Pendidikan Teknik Elektro, 3(2).

Radyuli, P., Sefriani, R. S., \& Qomariah, N. (2019). pembelajaran inquiry menggunakan google form terhadap hasil belajar simulasi dan komunikasi digital. edukatif: jurnal ilmu pendidikan, 1(2), 56-63.

Aththibby, A. R. (2015). Pengembangan media pembelajaran fisika berbasis animasi flash topik bahasan usaha dan energi. Jurnal Pendidikan Fisika, 3(2).

Potter, James W. (2005). Media Literacy.London: Sage Publication 